\title{
Summer monsoon climate simulations over BIMSTEC countries using RegCM4 regional climate model
}

\author{
Prasanta Kumar BaL ${ }^{1,2, *}$ and Ashis K Mitra ${ }^{1}$ \\ ${ }^{1}$ National Centre for Medium Range Weather Forecasting, Ministry of Earth Sciences, Noida 201 309, India. \\ ${ }^{2}$ Present address: DST Centre of Excellence in Climate Modelling, Centre for Atmospheric Sciences, \\ Indian Institute of Technology Delhi, New Delhi 110 016, India. \\ ${ }^{*}$ Corresponding author.e-mail: prasantbal.cc@gmail.com
}

MS received 26 June 2018; revised 28 March 2019; accepted 11 April 2019; published online 19 June 2019

Regional climate models are useful by downscaling from global climate model simulations for climate studies and climate applications at a regional scale. The South Asian monsoon region is one of the most challenging regions towards understanding the monsoon variability by implementing various climate simulations. A model version of the RegCM4 regional climate model provided by the International Centre for Theoretical Physics (ICTP) is used in this study to simulate the climate of Bay of Bengal Initiative for Multi-Sectoral Technical and Economic Cooperation (BIMSTEC) countries (India, Bangladesh, Bhutan, Nepal, Myanmar, Thailand and Sri Lanka) during the periods 1985-2000, which shows the present-day climate simulations. The simulation is carried out with RegCM4.3 with the lateral boundary forcing provided by the European Center for Medium Range Weather Forecast Reanalysis (Era-Interim) at $25 \mathrm{~km}$ horizontal resolution. The convective scheme Grell with closures Arakawa-Schubert is investigated during the south-west monsoon seasons (June-September, JJAS). The results indicate that the JJAS surface mean temperature has a large cold bias of $2-6^{\circ} \mathrm{C}$ over the coastal regions near India, Myanmar, Thailand, Sri Lanka and Bangladesh when compared with the Climate Research Unit (CRU) observed dataset. The model is able to produce the spatial rainfall distribution pattern of the observed CRU and Global Precipitation Climatology Project (GPCP) averaged seasonal rainfall in most of the land regions over the BIMSTEC countries during this period, but with underestimation. Further, the south-westerly prevailing wind pattern at $850 \mathrm{hPa}$ pressure level is also well captured by the model but with a higher intensity over Sri Lanka, Western India, Nepal and Thailand. The westerly is stronger over the Bay of Bengal in the model simulations than the observed Era-Reanalysis data sets obtained from ECMWF. Also, the model is able to capture the mean monsoon circulation features. This model may be used for a few of the BIMSTEC regions for climate study applications.

Keywords. RegCM4; monsoon; BIMSTEC.

\section{Introduction}

Seven-member countries - India, Bangladesh, Bhutan, Nepal, Myanmar, Thailand and Sri Lanka are adjacent to the Bay of Bengal and have areas of cooperation through a regional organisation, the Bay of Bengal Initiative for Multi-Sectoral Technical and Economic Cooperation (BIMSTEC; BIMSTEC Report 2014). These member countries are part of South Asia and South-East Asia, which 
are most vulnerable to climate change and are seriously affected by agricultural production and natural resources for the past few years. Summer monsoon is a dominant feature over South Asia where there is a large spatial variation of rainfall due to differences in location and its topography. In this aspect, considerable attention has been paid towards understanding the Asian monsoon variability by implementing various regional climate models (RCMs). Further, RCMs are the best tools for dynamical downscaling of climate features for obtaining detailed information for a particular region (Giorgi et al. 1993). Dynamical downscaling from RCM outputs is important in understanding the temperature and rainfall variability at a regional scale. A number of studies have been conducted in which the response of the summer monsoon to the enhanced greenhouse gases over the Asian domain has been reported by using outputs from different global climate models (GCMs) or through dynamical downscaling using high-resolution RCMs driven with many GCMs as the boundary conditions (Rupa Kumar and Ashrit 2001; Kripalani et al. 2007; Mukhopadhyay et al. 2010; Bhaskaran et al. 2012; Bal et al. 2015, 2016; Partha Sarathi et al. 2015; Sooraj et al. 2015; Anubhav and Domri 2017; Iqbal et al. 2017). Results from their studies show that the high-resolution RCMs are able to capture the distribution of monsoon rainfall in the spatial and temporal scales over the Asian domain and the model compares well with the observation.

RegCM4, developed by International Centre for Theoretical Physics (ICTP), is being widely used for seasonal simulation in the last decades. The performance of the model is also evaluated for the monsoon rainfall and surface temperature over the South Asian region. A number of sensitivity studies on different convection schemes have been conducted to find out the model performances with suitable schemes for simulation over the South Asian region by using the RegCM4 model (Dash et al. 2006; Sinha et al. 2013; Halder et al. 2015; Nayak et al. 2017; Pattnayak et al. 2017), and their results suggested that the spatial distribution of simulated rainfall by using the Grell parameterisation of convection scheme (Grell 1993; Grell et al. 1994) is closer to the observations than by using other schemes. Although the RegCM4 model has been widely used for different regional climate change studies, it has not been extensively examined so far over the BIMSTEC region. So far, little attention has been paid to simulate the RegCM4 model and the uncertainty in terms of temperature and rainfall variability arising from RegCM4 when compared to the observation over a few of the BIMSTEC countries. The purpose of this study was to examine the performance of the RegCM4 model simulating the monsoon temperature, rainfall and circulation features over the BIMSTEC countries. To assess the ability of the model to produce realistic projections of future climate change, the 'mean climate state', which is the historical 20th century (1985-2000) climate simulation of the model, is compared against the observations. It is expected that the improved understanding on these issues will be useful to use this model for the projections of future climatology for the countries.

\subsection{Current climatology of BIMSTEC countries}

Here, we are discussing only some of the salient features of observed climatology in terms of temperature, rainfall variability with monsoon circulation over different countries in the BIMSTEC region.

\subsubsection{India}

India has boundaries at the north of the equator between latitudes $8^{\circ} 4^{\prime}-37^{\circ} 6^{\prime} \mathrm{N}$ and longitudes $68^{\circ} 7^{\prime}-97^{\circ} 25^{\prime} \mathrm{E}$, bounded by the Arabian sea on the west and Bay of Bengal on the east and the country borders Bangladesh, Myanmar, Bhutan and Nepal with the Himalayan mountain surrounded on the northern parts. As per the Climate Profile for India (2010), summer starts in India from March and ends in early June with maximum temperatures rising sharply and exceeding $45^{\circ} \mathrm{C}$ by the end of May in the north and north-west regions of the country including the states of Gujarat, North Maharashtra, Rajasthan and North Madhya Pradesh. The normal annual rainfall in the country is about $1182.8 \mathrm{~mm}$. During the summer monsoon season (June-September), the country as a whole receives $70-90 \%$ of its annual rainfall (Pant and Rupa Kumar 1997). The heaviest rains occur over the hilly states in the north-east and along the mountainous west coast (Western Ghats), which is approximately $3760 \mathrm{~mm}$ of rainfall during the monsoon season. By contrast, the north-west of India, which includes the Rajasthan desert, receives a low annual average rainfall of $250 \mathrm{~mm}$. 


\subsubsection{Bangladesh}

Bangladesh is located near the head Bay of Bengal in the delta of the Ganges, Brahmaputra and Meghna and it lies between latitudes $20^{\circ} 34^{\prime}-$ $26^{\circ} 38^{\prime} \mathrm{N}$ and longitudes $88^{\circ} 01^{\prime}-92^{\circ} 42^{\prime} \mathrm{E}$. It is bordered on the west, north and east by India, on the south-east by Myanmar and on the south by the Bay of Bengal. It is likely to be one of the most vulnerable countries of the world to be affected by the effect of climate change and its impact most likely comes from the Bay of Bengal, which is the source of tropical cyclones and storm surges, monsoon wind, floods and droughts (Ali 1999; Mizanur et al. 2012). About $70-80 \%$ of Bangladesh's rain falls during the monsoon season (June-September) and most parts of the country receive at least 2000 $\mathrm{mm}$ of rainfall per year with a wide spatial and temporal distribution. The annual rainfall ranges from $1200 \mathrm{~mm}$ in the extreme west to over $5000 \mathrm{~mm}$ in the east and north-east (MPO 1991) and maximum summer temperatures range between $32^{\circ} \mathrm{C}$ and $38^{\circ} \mathrm{C}$.

\subsubsection{Bhutan}

Bhutan is situated between latitudes $26^{\circ} 45^{\prime}-$ $28^{\circ} 10^{\prime} \mathrm{N}$ and longitudes $88^{\circ} 45^{\prime}-92^{\circ} 10^{\prime} \mathrm{E}$. It is bordered by the Tibetan region of China on the north and by India on the west, south and east. The mountainous terrains range from an elevation of $100 \mathrm{~m}$ above sea level in the south and reach over $7550 \mathrm{~m}$ in the north. About $72 \%$ of the country's land area is covered by forests. The country receives $60-90 \%$ of its total annual rainfall during the summer monsoon season. The southern belt has a hot, humid climate, with temperatures remaining fairly even throughout the year between $15^{\circ} \mathrm{C}$ and $30^{\circ} \mathrm{C}$ and annual rainfall ranging between $2500 \mathrm{~mm}$ and above over the southern belt, $1000 \mathrm{~mm}$ over the central inner Himalayas region and $400 \mathrm{~mm}$ over the northern region (Alam and Tshering 2004).

\subsubsection{Nepal}

The geographical limits of Nepal lie between latitudes $26^{\circ} 22^{\prime}-30^{\circ} 27^{\prime} \mathrm{N}$ and $80^{\circ} 04^{\prime}-88^{\circ} 12^{\prime} \mathrm{E}$ longitudes. The altitude varies from $60 \mathrm{~m}$ above mean sea level in the southern plain to the Mount Everest $(8848 \mathrm{~m})$ in the north-east. Eighty-six per cent of its total area is comprised of hilly and mountainous regions and the remaining $14 \%$ as flatland (Government of Nepal 2015). Nepal has an average annual precipitation of around $1800 \mathrm{~mm}$ and it receives $80 \%$ of its annual precipitation during the summer monsoon. Annual precipitation is less than $1000 \mathrm{~mm}$ in north-western Nepal, where elevations exceed $3000 \mathrm{~m}$ (Kimpei et al. 2007). During the monsoon season, total precipitation exceeds $200 \mathrm{~mm}$ in all areas except north-west Nepal and precipitation exceeds $800 \mathrm{~mm}$ in central and eastern Nepal. Further, during monsoon time, Nepal is dominated by the strong south-easterly wind from the Bay of Bengal which brings moisture to the central eastern part of Nepal but in the high Himalaya region, systems like western disturbances are equally effective as monsoon in bringing rainfall over the country (Shrestha et al. 1999; Sigdel and Ikeda 2012). Again, the mean annual maximum temperature is more than $30^{\circ} \mathrm{C}$ over the southern plains while it is below $0^{\circ} \mathrm{C}$ in the Himalayan range. The mean minimum temperature varied from above $16^{\circ} \mathrm{C}$ to $20^{\circ} \mathrm{C}$ in the southern part to less than $-8^{\circ} \mathrm{C}$ in the northern parts of the country.

\subsubsection{Myanmar}

Myanmar is located in southeast Asia between latitudes $9^{\circ} 32^{\prime}-28^{\circ} 31^{\prime} \mathrm{N}$ and longitudes $92^{\circ} 10^{\prime}-$ $101^{\circ} 11^{\prime} \mathrm{E}$. The Asia summer monsoon rainfall accounts for almost $90 \%$ of the observed rainfall over Myanmar (Parthasarathy et al. 1994; Gadgil et al. 2004). Myanmar's summer monsoon rainy season is experienced in June-September, and according to Sein et al. (2015), the summer monsoon rainfall accounts for about $43 \%$ of the total annual rainfall over Myanmar, which is nearly around $500 \mathrm{~mm}$. The annual average temperature ranges from $22^{\circ}$ to $27^{\circ} \mathrm{C}$ all year round. Annual rainfall is approximately $1000-2500 \mathrm{~mm}$, while average annual rainfall in the coastal regions is approximately $5000 \mathrm{~mm}$.

\subsubsection{Thailand}

Thailand is located in the tropical area between latitudes $5^{\circ} 37^{\prime}-20^{\circ} 27^{\prime} \mathrm{N}$ and longitudes $97^{\circ} 22^{\prime}-$ $105^{\circ} 37^{\prime} \mathrm{E}$. The climate of Thailand is under the influence of the south-west monsoon, which remains active between mid-May to early October, and the north-east monsoon, which starts in midOctober and causes rain all over the country. Further, during the south-west monsoon season, the south-westerly wind from the Indian Ocean brings moist air towards Thailand. Some of the moisture is blocked by the mountain ranges in Burma. 
In August, the north-easterly trade winds blow in the reverse direction, causing rainfall peaks during August to September (Roongroj and Long 2007). Annual rainfall of the country is between 1200 and $1600 \mathrm{~mm}$ and during March-May, the hottest period of the year, maximum temperatures usually reach near $40^{\circ} \mathrm{C}$ or more, except along coastal areas where sea breezes will moderate afternoon temperatures.

\subsubsection{Sri Lanka}

Sri Lanka is located at the southern tip of the Indian subcontinent, extending from latitudes $5^{\circ} 55^{\prime}-9^{\circ} 51^{\prime} \mathrm{N}$ to longitudes $79^{\circ} 42^{\prime}-81^{\circ} 53^{\prime} \mathrm{E}$. Its mean annual rainfall varies from less than 1000 $\mathrm{mm}$ on the south-east coast to over $4500 \mathrm{~mm}$ on the western slopes of the highlands (Burt and Weerasinghe 2014). Seasonal variation in rainfall is determined by the south-west monsoon (MarchAugust and the north-east monsoon (SeptemberFebruary). In the inter-monsoon seasons, Sri Lanka is influenced by tropical cyclones, depressions and thunderstorms associated with migration of the inter-tropical convergence zone.

\section{Methodology}

The RegCM4 regional climate model has been used in this study with horizontal resolutions of $0.22^{\circ} \times$ $0.22^{\circ}$ or $25 \times 25 \mathrm{~km}$ with 18 levels in the atmosphere. The LBCs from the GCM Era-Interim are used in this study to force the RegCM4 simulations over the BIMSTEC domain, which extends from $60^{\circ} \mathrm{E}$ to $110^{\circ} \mathrm{E}$ and from $0^{\circ} \mathrm{S}$ to $38^{\circ} \mathrm{N}$. The individual country boundaries are depicted in figure 1 . In this study, only mean surface air temperature, rainfall and lower level monsoon circulation are analysed to examine the model performances against the observation. The model simulations are performed for a present climate of 16 year (1985-2000) using the Grell convective scheme. The simulated rainfall and temperature during the period 1985-2000 is considered as the baseline period or the present-day climate simulation. The Special Report on Emissions Scenarios (SRES)

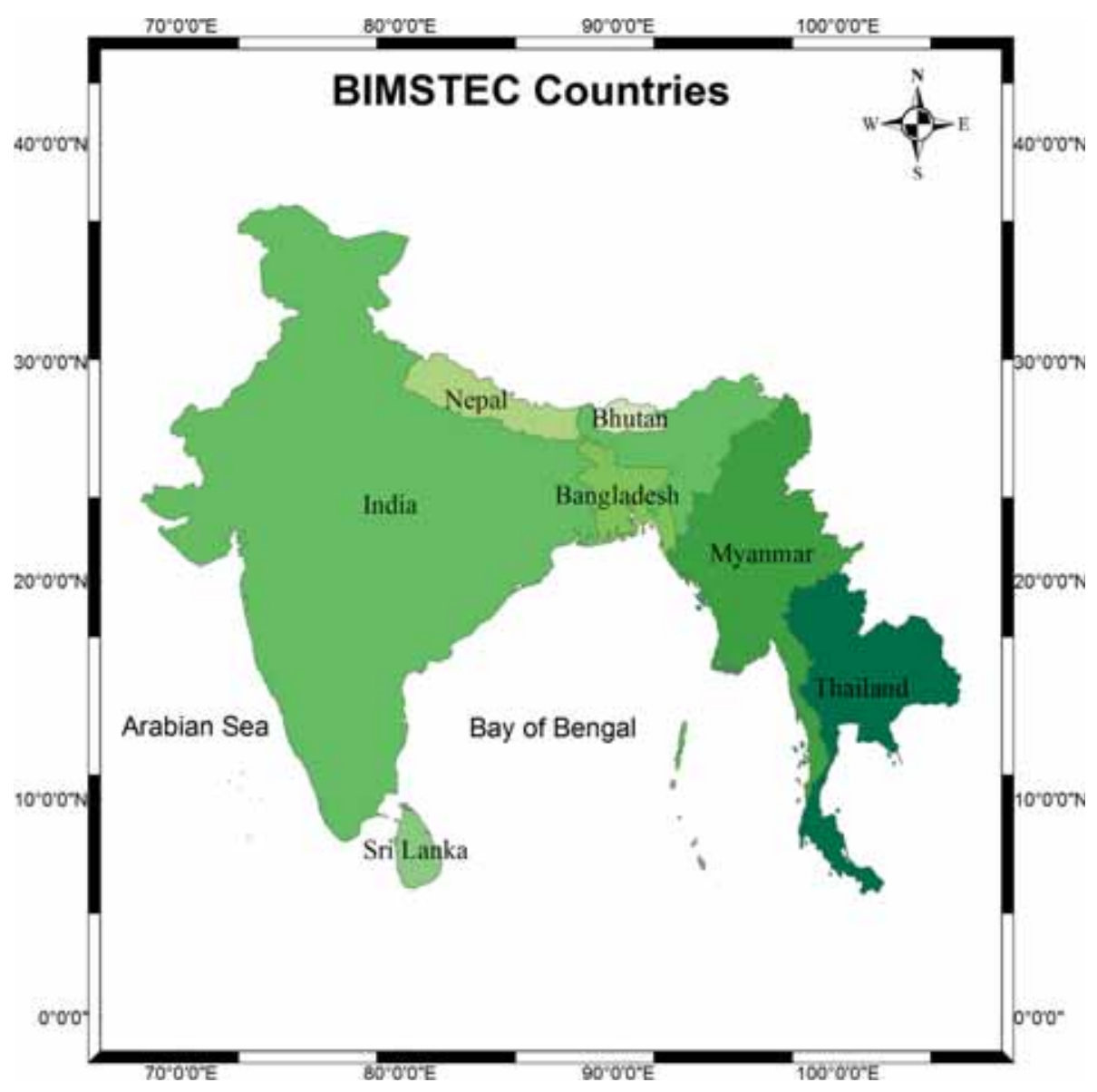

Figure 1. Study area which includes all the seven countries of the BIMSTEC region. 
Table 1. List of variables modified in input file to run the model.

\begin{tabular}{lll}
\hline $\begin{array}{l}\text { Simulation } \\
\text { parameter }\end{array}$ & \multicolumn{1}{c}{ Value } & \multicolumn{1}{c}{ Description } \\
\hline iy & 280 & Number of grid points in y direction (i) \\
jx & 320 & Number of grid points in x direction (j) \\
kz & 18 & Number of vertical levels (k) \\
ds & 25.0 & Grid point separation in km \\
ptop & 5.0 & Pressure of model top in cb \\
clat & 16.00 & Central latitude of model domain in degrees \\
clon & 76.00 & Central longitude of model domain in degrees \\
iproj & ROTMER & Map projection (Rotated Mercator) \\
ibyte & 4 & 4 for IBM (Supercomputer having 350TF of \\
& & processing speed and 1PB of storage) \\
IDATE1 & 1985060100 & Beginning date of simulation \\
IDATE2 & 2000100100 & Ending date of simulation \\
SSTTYP & OI_WK & OISST weekly dataset \\
DATTYP & EIN15 & Global analysis dataset \\
NPROC & 128 & Number of processors used for parallel computing \\
\hline
\end{tabular}

A1B of Era-Interim is used to drive the RegCM4 model. In addition, the Era-Interim dataset at 6-hourly intervals is used for the initial and boundary conditions and optimum interpolation sea surface temperature (OISST) $1^{\circ}$ (1981-2005) gridded data available from the National Ocean and Atmosphere Administration (NOAA) at weekly time scales (OI-WK) are used to make the simulations for the period 1985-2000. RegCM4 is coupled with the biosphere-atmosphere transfer scheme BATS and the National Center for Atmospheric Research (NCAR) Community Land Model version 4.5 (CLM4.5) has been used to understand the coupling between land and atmosphere for simulation of the Indian summer monsoon rainfall. The model experiment and the steps involved in creating the necessary initial and boundary conditions files are given in table 1 . The model simulations are evaluated against the CRU (Climate Research Unit) and GPCP (Global Precipitation Climatology Project) observation data sets. We have used the observed monthly rainfall and temperature dataset from CRU data, which is a global, land only dataset available at $0.5^{\circ} \times 0.5^{\circ}$ resolution. RegCM4 simulated mean temperature and seasonal rainfall are compared with the CRU observed data sets during the baseline period to understand the performance of the model. Further, for examining the model performances over both land and oceanic regions, the GPCP monthly rainfall data are used at a resolution of $2.5^{\circ} \times 2.5^{\circ}$ for the period 1985-2000. The spatial and temporal distributions of long-term averaged rainfall during the south-west monsoon over different countries of BIMSTEC have been compared with both CRU and GPCP observation data. The rainfall and temperature trends are also being calculated and compared by both the model and observations. Gridded reanalysis monthly observed zonal and meridional winds at $850 \mathrm{hPa}$ obtained at a horizontal resolution of $0.5^{\circ} \times 0.5^{\circ}$ from the European Centre for Medium-Range Weather Forecasts (ECMWF) (http://apps.ecmwf. int/datasets/data/interim-full-daily/levtype $=$ sfc $/$ ) are compared with RegCM4 to examine the summer monsoon circulation features during the period 1985-2000.

\section{Results and discussion}

\subsection{Surface temperature simulation}

Comparisons between the CRU observed and model simulated surface mean temperature spatial pattern and the differences (Model-CRU) for the averaged period of 1985-2000 during the monsoon season are shown in figure $2(\mathrm{a}-\mathrm{c})$. Observation shows that the mean temperature is higher (above $25^{\circ} \mathrm{C}$ ) over the western and central parts of India, $20-25^{\circ} \mathrm{C}$ in most places over Bangladesh, Myanmar, Thailand and Sri Lanka and $5-15^{\circ} \mathrm{C}$ over Nepal and Bhutan. RegCM4 simulation shows a cold bias of $2-6^{\circ} \mathrm{C}$ in land regions of most of the BIMSTEC region. The highest cold bias of more than $6^{\circ} \mathrm{C}$ is seen over the western parts and peninsular India. Bias is less over the coastal region 
(a) RegCM4

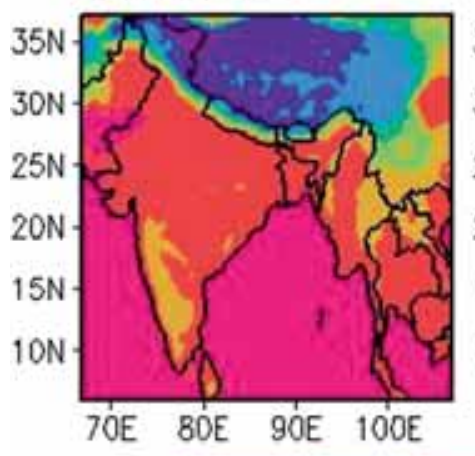

(b) CRU

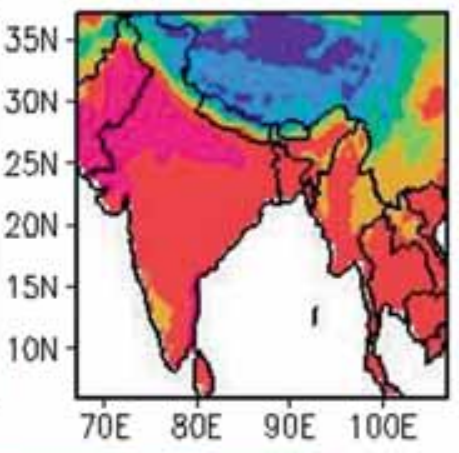

(c) Bias

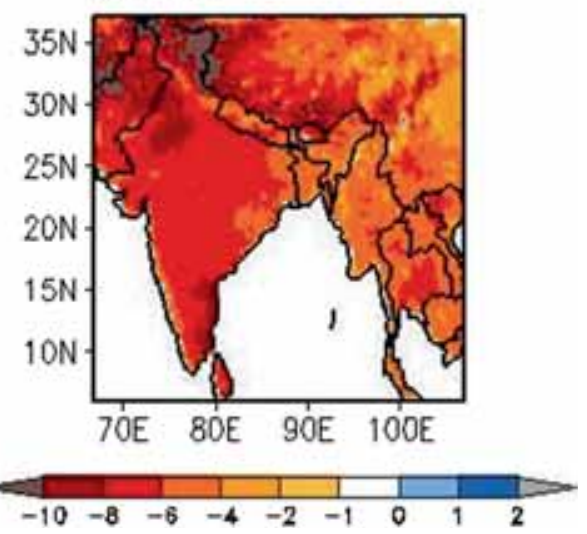

Figure 2. Simulated and observed JJAS mean surface air temperature $\left({ }^{\circ} \mathrm{C}\right)$ : (a) RegCM4 model, (b) CRU observed, and (c) bias (model - observed).

(a) $\mathrm{Reg} \mathrm{CM} 4$

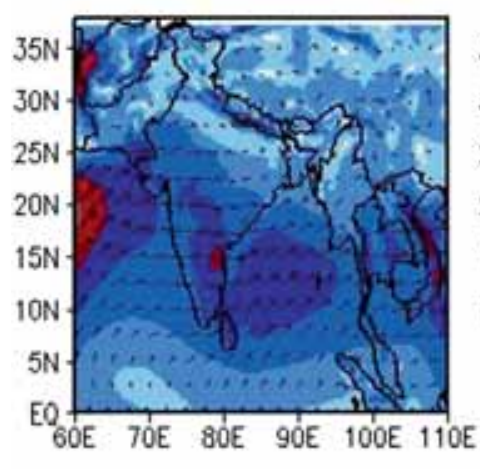

(b) Era-reanalysis

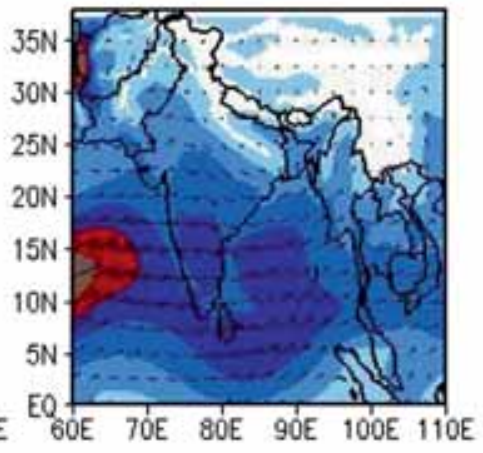

(c) Bias

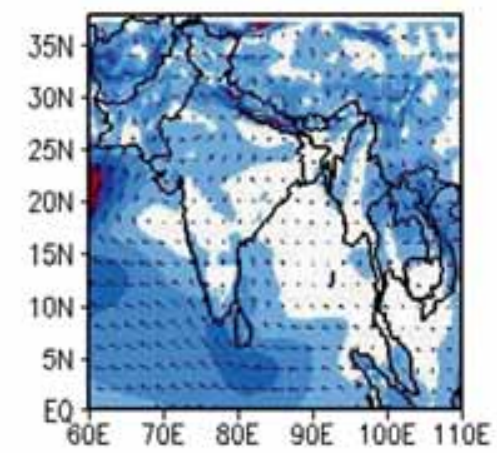

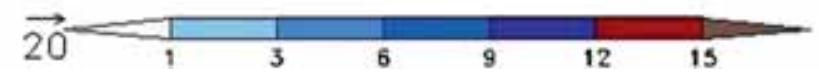

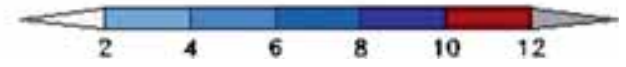

Figure 3. JJAS averaged low level wind $\left(\mathrm{m} \mathrm{s}^{-1}\right)$ at $850 \mathrm{hPa}$ level: (a) winds simulated by the RegCM4 model, (b) Era-Interim reanalysis, and (c) differences in wind (model - reanalysis).

near India, Myanmar, Thailand, Sri Lanka and Bangladesh but it is more over the mountainous region, northern India, north-west part of India and the adjoining region. Further, there is a temperature gradient from southern parts and the west coast of India covering the Western Ghats to central India, which is well simulated in the model. Overall, the model shows that a cold bias persists over most of the BIMSTEC regions.

\subsection{Simulations of monsoon circulation}

In this section, the important characteristics of the monsoon circulation features at the lower level tropospheric level $(850 \mathrm{hPa})$ are studied in detail and shown in figure $3(\mathrm{a}-\mathrm{c})$. It is found that the monsoon trough, a narrow belt of strong south-westerly winds, which is a low-pressure area covering northwest India and the adjoining area up to the north
Bay of Bengal, is simulated well during the summer monsoon season using the RegCM4 model. The model realistically captures the general structure of the lower level tropospheric circulations. However, some discrepancies are observed in the model simulations. From the Era-reanalysis observation data, it is noticed that the strong westerly flows over the western parts of India and a cyclonic circulation feature over the central part of India are developed during this period. This is well captured in the model simulation but cyclonic circulation over central India and the south westerlies near the Western Ghats and southern peninsular Indian region is weaker when compared with the observation. Over Nepal and Bhutan, the northerly winds are stronger than in the observation. Over Myanmar and Thailand, the westerly flow is slightly stronger in the model than in the observation. It shows that the maximum strength of the JJAS 


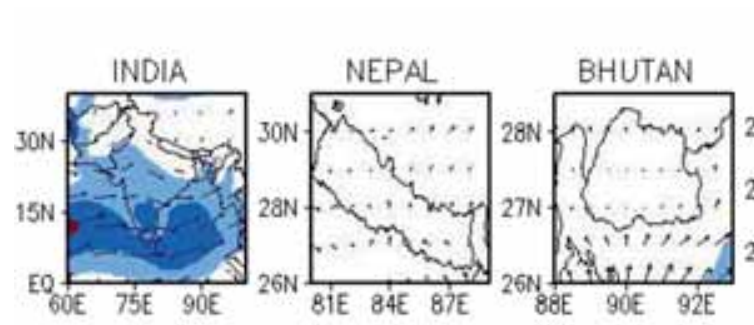

JUNE.
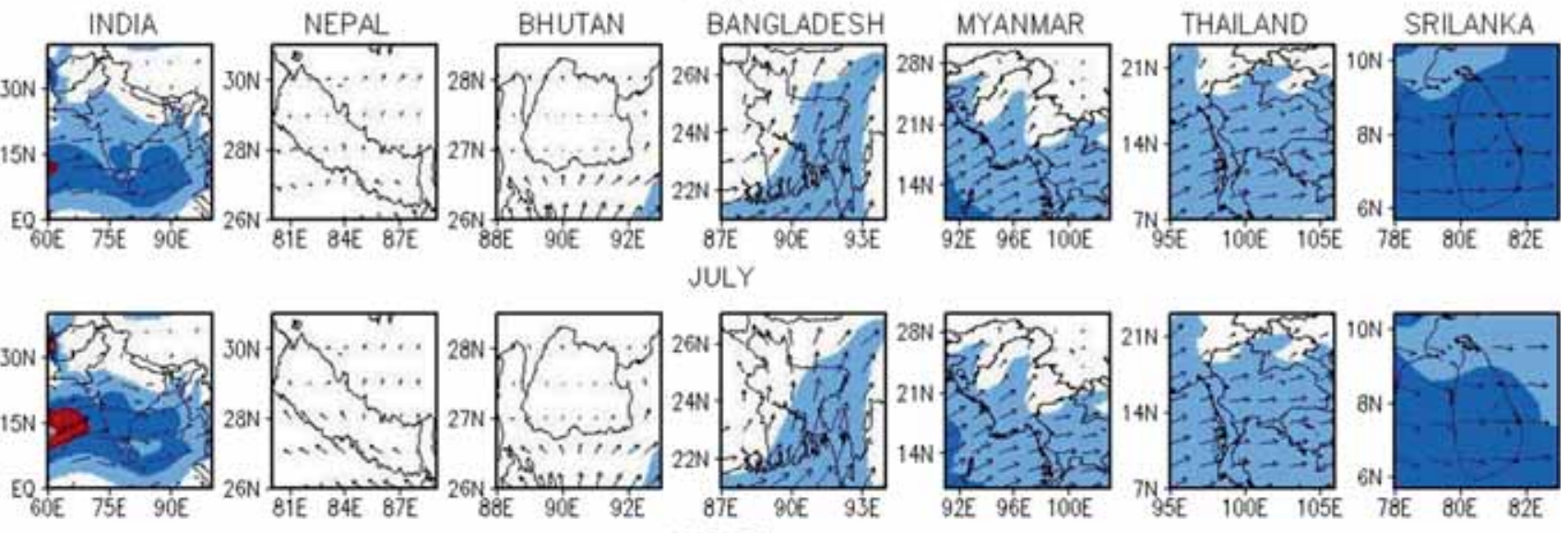

JULY
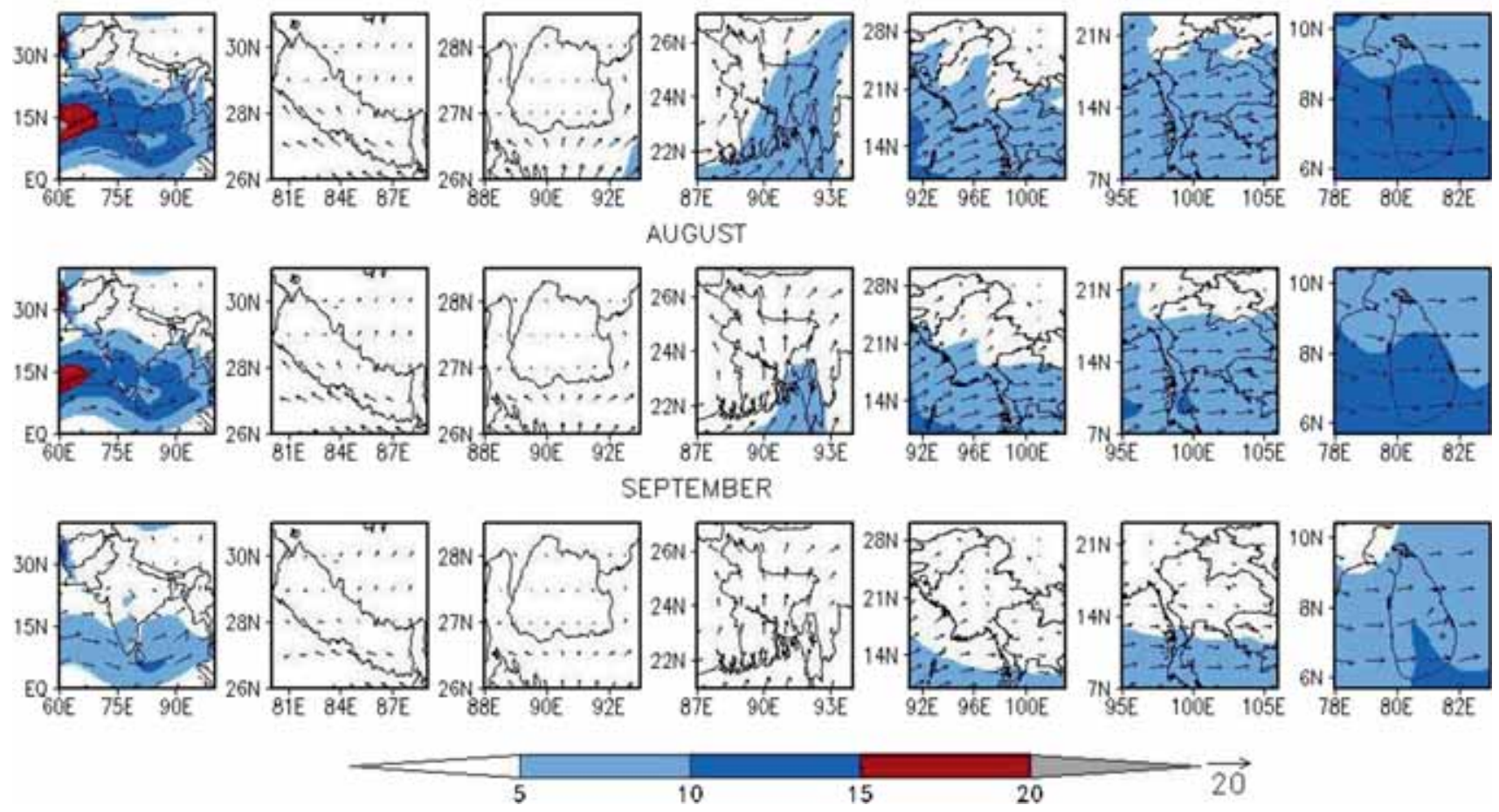

Figure 4. Average wind at $850 \mathrm{hPa}$ for the months June, July, August and September for Era-Reanalysis winds based on the period 1985-2000 over the BIMSTEC countries.

mean westerly wind is $9-12 \mathrm{~m} \mathrm{~s}^{-1}$ over the Bay of Bengal and 12-15 $\mathrm{m} \mathrm{s}^{-1}$ over the Arabian Sea in both the observation and the model. Maximum wind speed at the core of the Somali jet as simulated by the model is above $12-15 \mathrm{~m} \mathrm{~s}^{-1}$. The model produces a slightly weaker cross equatorial flow and Somali jet (easterly bias) and a stronger wind over the north Arabian Sea (westerly bias). The magnitudes of bias vary from 2 to $4 \mathrm{~m} \mathrm{~s}^{-1}$ over all the BIMSTEC countries, except for Nepal and Bhutan, where it shows the maximum bias of $8-12 \mathrm{~m} \mathrm{~s}^{-1}$ and the direction is south-westerly when compared to the observation. Again, the major discrepancy between analysis and model simulation is the strong westerly winds associated with a trough over Bangladesh, Myanmar and Thailand, which is weaker in the model. Other than that, the model is able to capture the strength and the direction of the lower tropospheric westerlies.
Figures 4 and 5 show the JJAS averaged monsoon circulation features at $850 \mathrm{hPa}$ over individual BIMSTEC countries from the Era-Interim observation and the model simulation, respectively. It is observed that a strong south-westerly flow and formation of cyclonic circulation features associated with the trough over the North Bay of Bengal is seen over coastal part of India, Bangladesh, Myanmar and Thailand during June-September. It is noticed that RegCM4 simulations show reasonable skill to represent the westerly flow over Myanmar and Thailand and southerly over the Bangladesh region. However, the westerly is stronger in the model simulations than in the observed Era-Reanalysis. In overall, the model simulated circulation is stronger than the observed circulation and also spans over larger area than the observed. Further, a strong westerly wind dominated the northern part of Sri Lanka in the simulation during the JJAS, from the Arabian Sea to the Bay of 

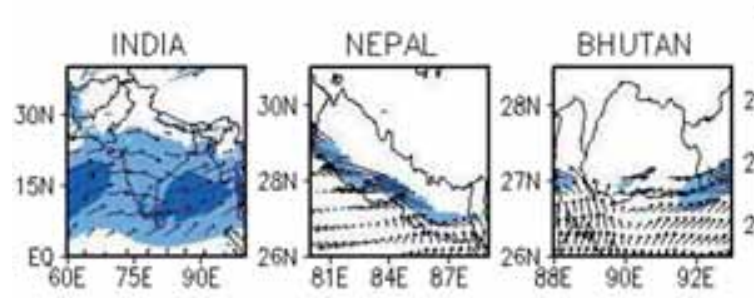

JUNE
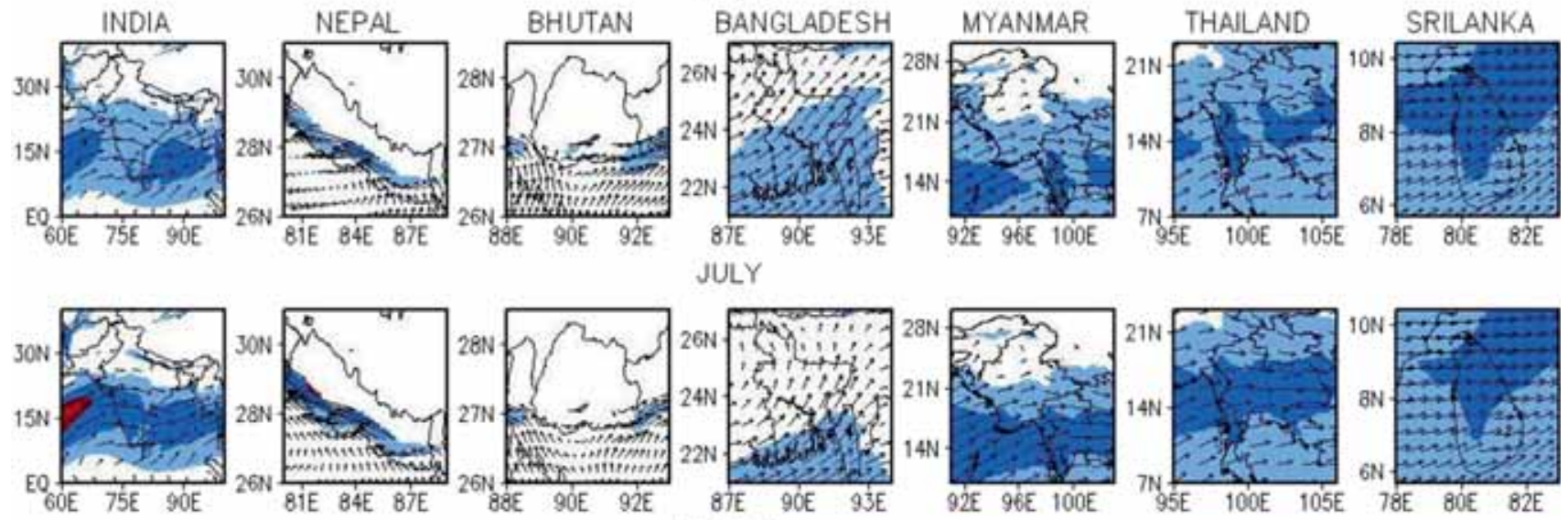

\section{JULY}
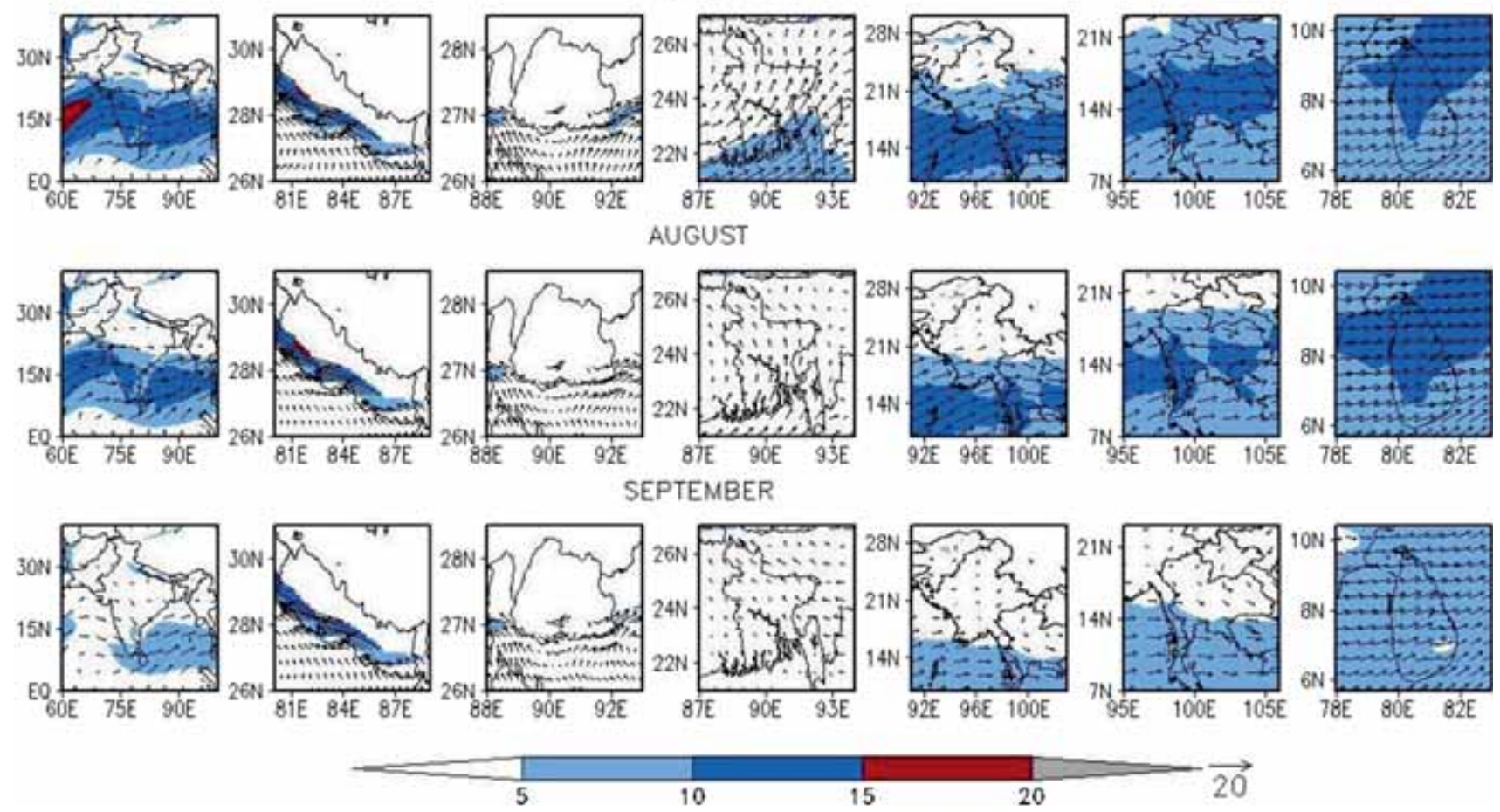

Figure 5. Same as figure 4, but for RegCM4 simulation.

Bengal, which is weaker in the observation. Also, the re-curving of westerlies over the head Bay of Bengal is well pronounced and the weakening of the wind speed from June through September, which is seen in the observation, is represented well in the model simulations.

\subsection{Rainfall simulations}

Seasonally averaged rainfall over the BIMSTEC region using RegCM4 has been studied in detail to evaluate the model skills during the period 1985-2000. The temporal trend of seasonal rainfall for the individual country computed from the model simulation and CRU observation is shown in figure 6. It is seen that the daily mean rainfall simulated during the JJAS period matches well with the observation for countries like India, Myanmar and Thailand (area averaged). However, the model underestimates over Bhutan, Nepal and Bangladesh and overestimates over Sri Lanka.
Further, the rainfall spatial distribution of the model simulated, the CRU observation and model bias for the same period is shown in figure $7(\mathrm{a}-\mathrm{c})$. It is found that the model captures well the rainfall distributions over a few places over BIMSTEC such as the Western Ghats in India, parts of central India, coastal Myanmar and Bangladesh, but with less magnitude. It is noticed that the model shows dry bias over some parts of Myanmar and the north-eastern part of India and the magnitude of dry bias shows within the range 10$50 \mathrm{~mm}$ day $^{-1}$. Wet bias is noticed over the Western Ghats, Southern peninsular India, Sri Lanka and parts of Thailand where rainfall overestimates 2-10 mm day ${ }^{-1}$. Over Sri Lanka and south-west Thailand, wet bias is observed with a magnitude of 10-50 mm day ${ }^{-1}$.

Further, to investigate the similar sensitivity over both the land and oceanic regions, the rainfall spatial distribution and corresponding bias are analysed by taking the model simulated and 
Indio
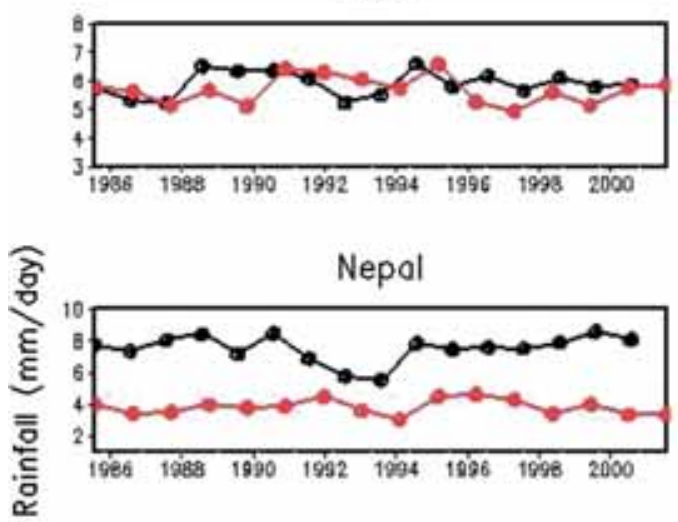

Srilanka

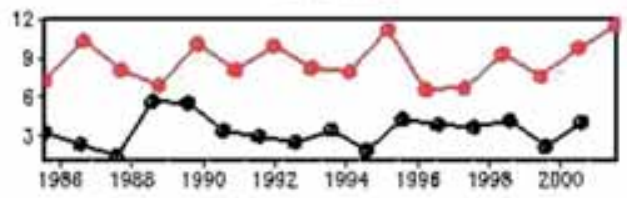

Thailand

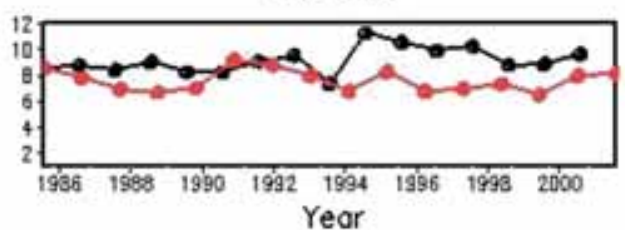

Bhuton
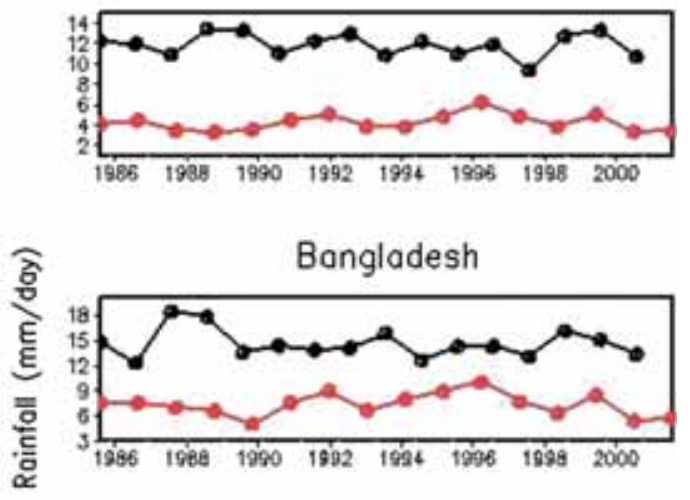

Myanmar

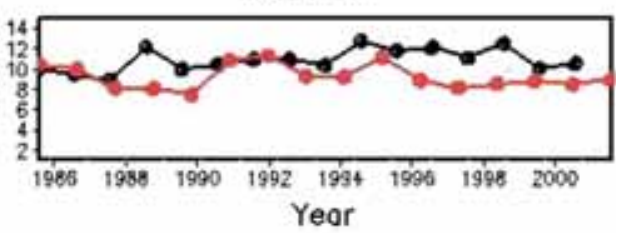

CRU(Observed)

RegCM4(Model)

Figure 6. Temporal trend of simulated and observed JJAS rainfall ( $\left.\mathrm{mm} \mathrm{day}^{-1}\right)$ from 1985 to 2000 over the different countries of BIMSTEC.

(a) RegCM4

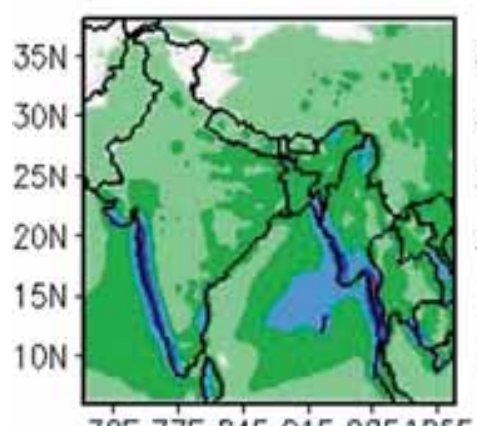

7DE 77E 84E 91E 98E 105E (b) CRU-Observed

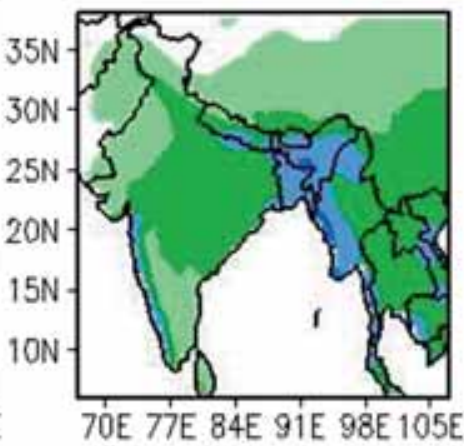

(c) Bias

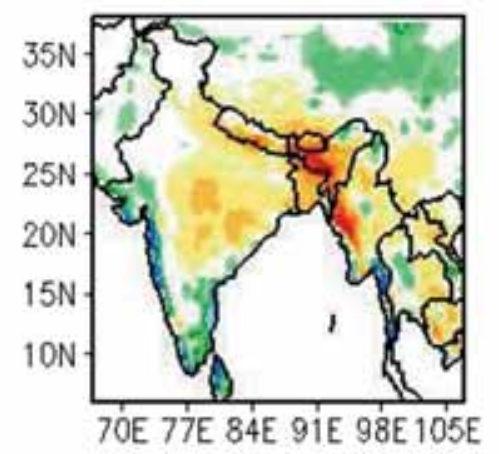

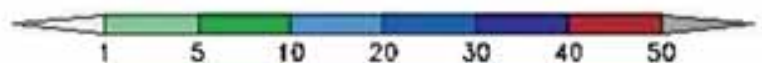

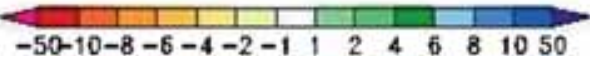

Figure 7. Simulated and observed JJAS averaged daily rainfall $\left(\mathrm{mm} \mathrm{day}^{-1}\right)$ : (a) RegCM4 model, (b) CRU observed, and (c) bias (model - observed).

the GPCP observed rainfall (figure $8 \mathrm{a}-\mathrm{c}$ ). The spatial distribution of seasonal rainfall shows rainfall of $10-30 \mathrm{~mm} \mathrm{day}^{-1}$ over the head Bay of Bengal, eastern and north-eastern regions of India, Bangladesh and Western Myanmar in the GPCP observation, whereas the model is able to represent the rainfall patterns over the land regions but with underestimation. The dry bias is more over a few regions in Myanmar and north-eastern India. In order to better explain the model performances over each of the individual BIMSTEC countries, the seasonally averaged spatial rainfall 
(a) RegCM4

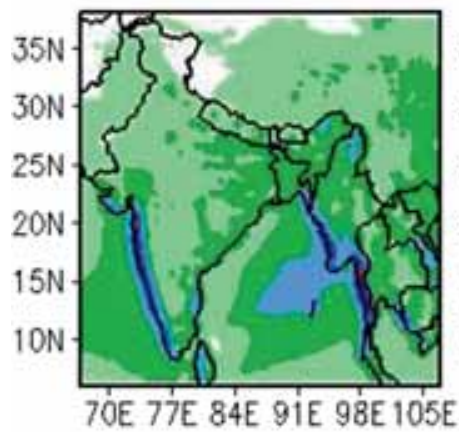

(b) GPCP-Observed

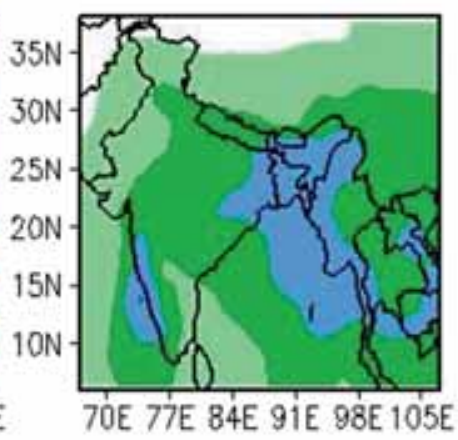

(c)Bias

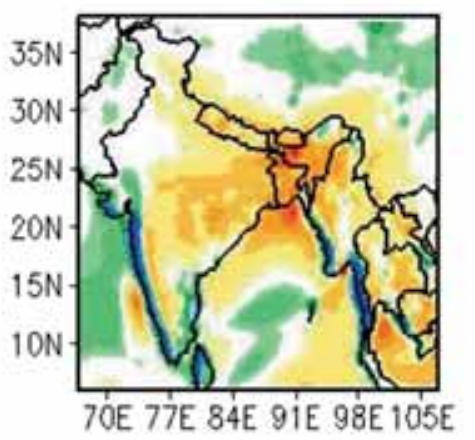

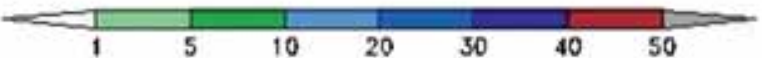

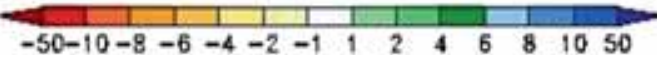

Figure 8. Same as figure 7, but for GPCP observation.
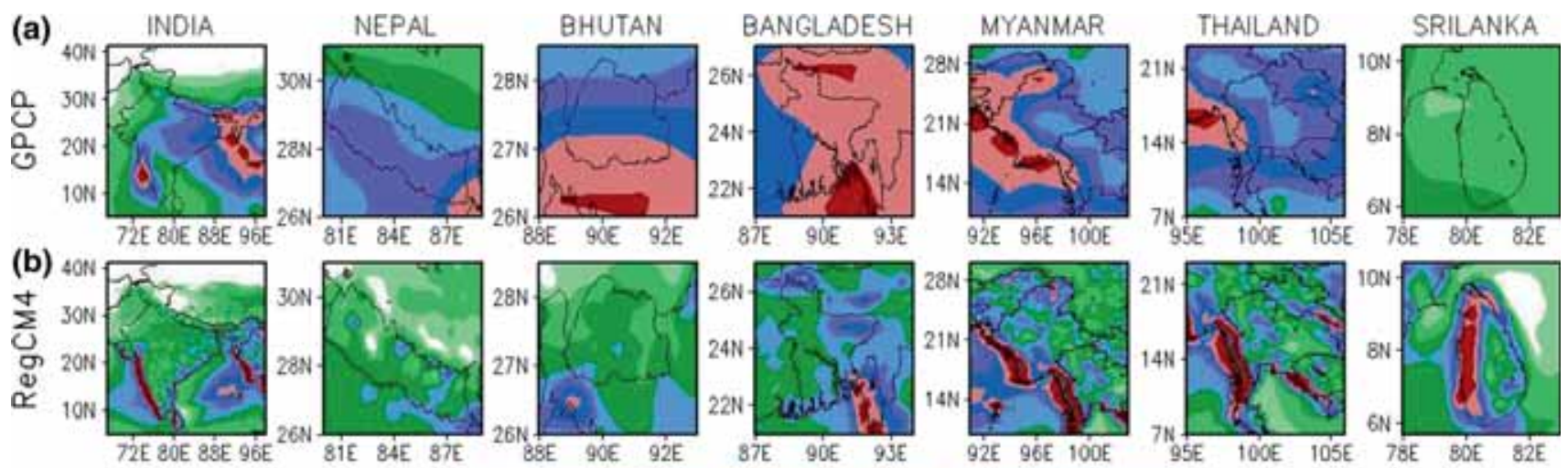

(c)
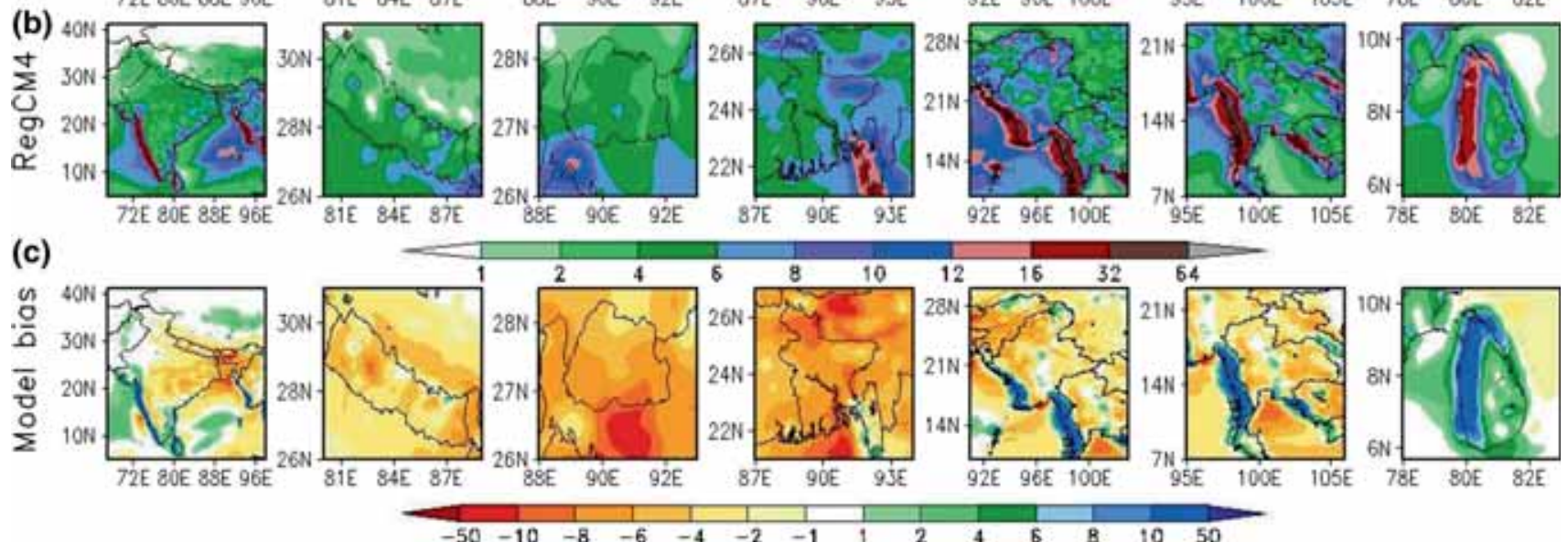

Figure 9. Simulated and observed JJAS averaged rainfall $\left(\mathrm{mm} \mathrm{day}^{-1}\right)$ during the period 1985-2000 and corresponding bias with GPCP observed rainfall over individual BIMSTEC countries: (a) GPCP observed, (b) RegCM4 model, and (c) bias (model - observed).

distribution for the period 1985-2000 both from the model and GPCP observation with rainfall bias is shown in figure $9(\mathrm{a}-\mathrm{c})$. It is found that during JJAS, the model considerably underestimates rainfall over most of the areas of BIMSTEC countries. From the observation, it is seen that the West Coast of India, Central India, North-East India, South Nepal, South Bhutan, most parts of Bangladesh, western Myanmar, southern Myanmar and west Thailand receive rainfall of 10-32 $\mathrm{mm}$ day $^{-1}$ during the monsoon season, whereas the model-simulated rainfall shows lesser in magnitude as a dry bias of $4-10 \mathrm{~mm}$ day $^{-1}$ over the above-mentioned regions when compared with the observation. Further, over the western part of Sri Lanka, a large wet bias of $10-50 \mathrm{~mm} \mathrm{day}^{-1}$ is found.

Further, we have considered a few homogeneous regions over BIMSTEC countries to investigate the model performance on a regional scale. The regions in different BIMSTEC countries are considered as follows: Central India $\left(77-86^{\circ} \mathrm{E} ; 18-24^{\circ} \mathrm{N}\right)$, South Nepal $\left(84-88^{\circ} \mathrm{E} ; 26-28^{\circ} \mathrm{N}\right)$, South Bhutan $\left(89-92^{\circ} \mathrm{E} ; 26.5-28^{\circ} \mathrm{N}\right)$, East Bangladesh $\left(90-92^{\circ} \mathrm{E}\right.$; $\left.22-25^{\circ} \mathrm{N}\right)$, West Myanmar $\left(92-96^{\circ} \mathrm{E} ; 14.5-21^{\circ} \mathrm{N}\right)$, West Thailand $\left(96-100^{\circ} \mathrm{E} ; 9-15^{\circ} \mathrm{N}\right)$ and South 
(a) Central India

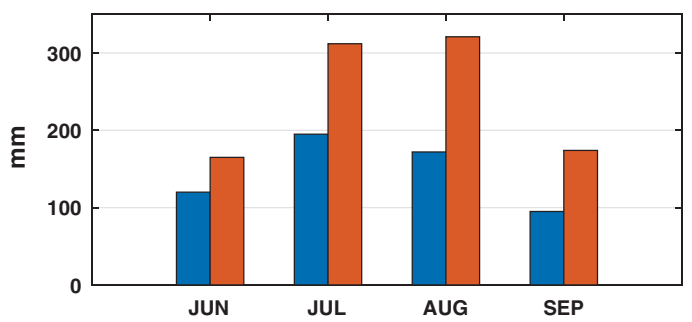

(c) South Bhutan

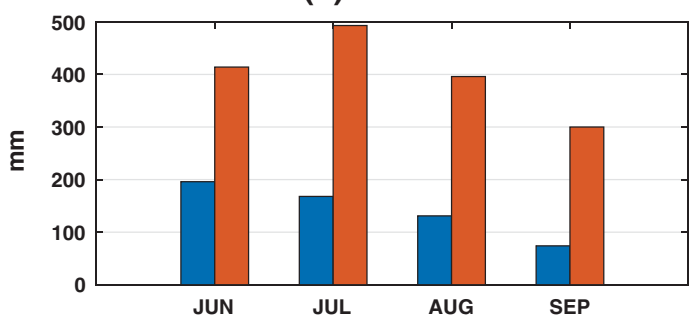

(e) West Myanmar

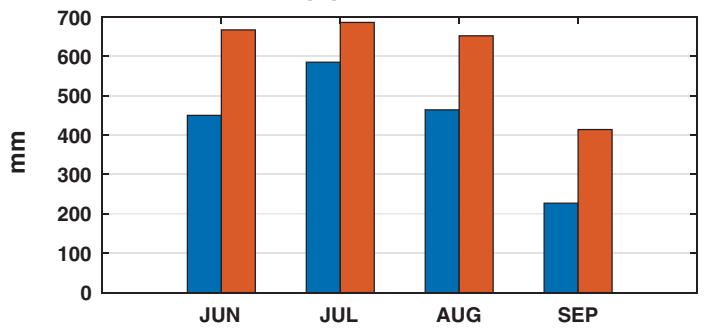

(g) South Srilanka

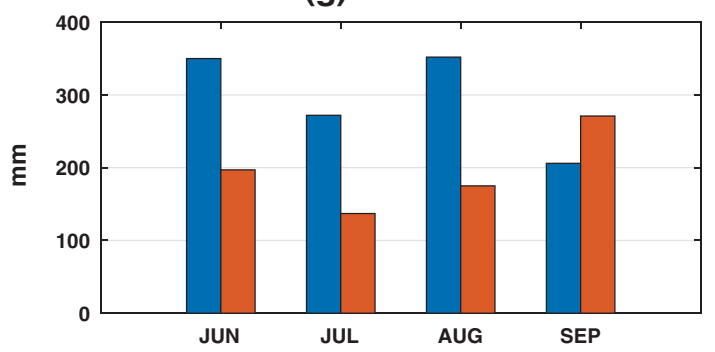

(b) South Nepal

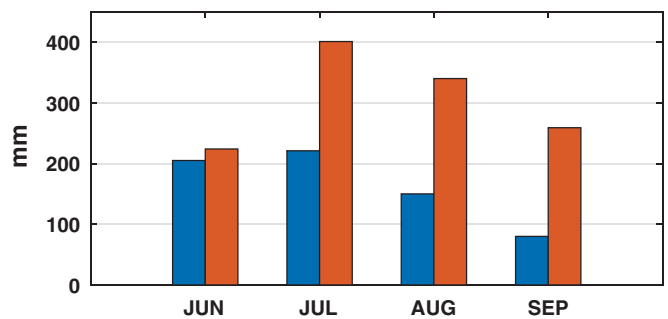

(d) East Bangladesh

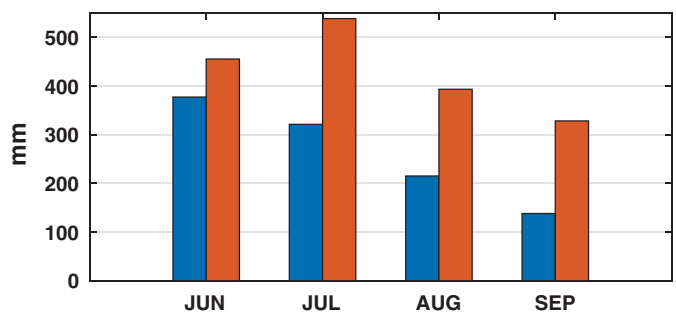

(f) West Thailand

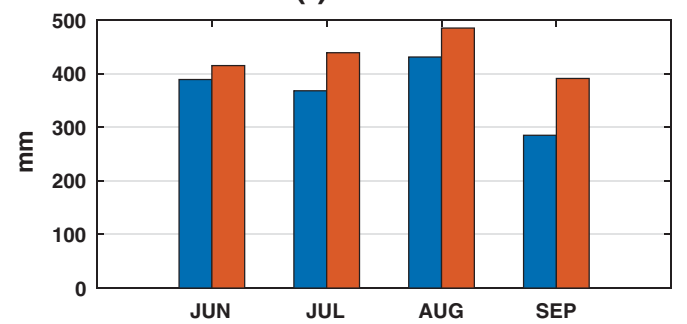

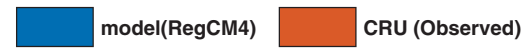

Figure 10. Month-to-month variability of summer monsoon rainfall (cumulative rainfall in $\mathrm{mm}$ ) from June to September over seven homogeneous regions of BIMSTEC countries based on CRU observation and RegCM4 model simulation.

Sri Lanka $\left(80-81^{\circ} \mathrm{E} ; 6-7^{\circ} \mathrm{N}\right)$. Our identification of homogeneous rainfall regions is based on the zones of the rainfall maxima during the monsoon season. For example, we have considered only the Central Indian region from the different core monsoon regimes of India that include the Western Ghats, North-East India, foothills of Himalaya and Central India. Likewise, regions that fall in zones of rainfall maxima are considered for other countries included in BIMSTEC. Monthly variations of cumulative rainfall from both the model and the CRU observation over these seven regions are shown in figure $10(\mathrm{a}-\mathrm{g})$. It is clear from the figure that except for the South Sri Lanka region, the model in all the regions underestimates the rainfall during each of the months from June to September. Cumulative rainfall in each month over most of the regions is significantly lesser (100-200 mm) than the observation. The model performance also evaluated computation of the rainfall probability density function (PDF) over these seven homogeneous regions. The objective is to compare the intensities of rainfall extremes for different regions of BIMSTEC countries. The salient features of daily rainfall $\mathrm{PDF}$ distribution over the different homogeneous regions of BIMSTEC countries are shown in figure 11. Daily rainfall intensity between different categories is shown on the $x$-axis and 


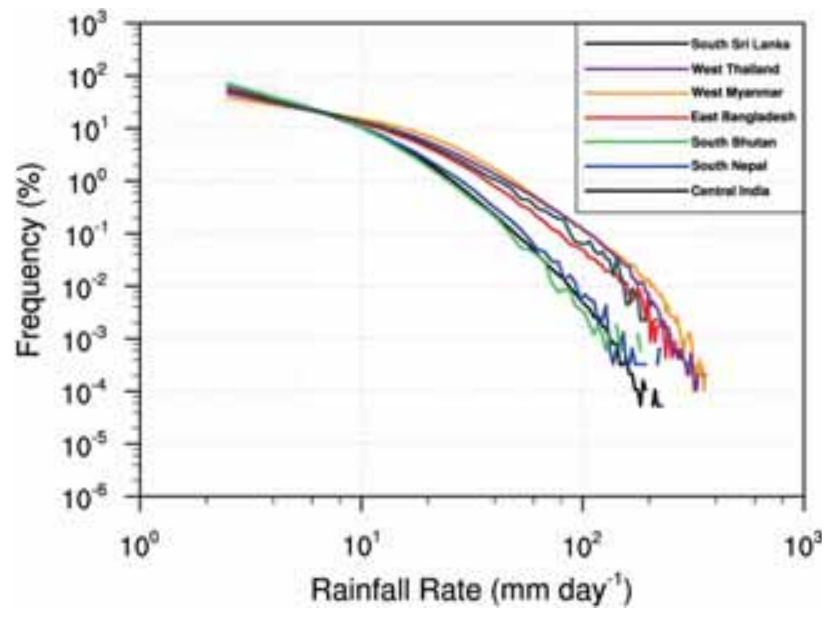

Figure 11. PDF distribution of RegCM4 simulated daily rainfall over different regions of BIMSTEC countries across all years (1985-2000). The $y$ values over the $x$-axis represent the occurring probability (in \%) for each rainfall range.

frequency (in \%) is shown on the $y$-axis. The PDF distribution during the monsoon season is quite similar for all the countries. A common feature related to $\mathrm{PDF}$ distribution of daily rainfall for all the regions shows that the lower the rainfall intensity $\left(0-10 \mathrm{~mm} \mathrm{day}^{-1}\right)$, the more frequently it occurs as the frequency reaches near $90 \%$, and conversely, the higher the rainfall intensity, the less frequently it occurs (frequency reduces to 0.001 , i.e., $\left.10^{-3}\right)$. The major differences exist in medium-intensity (10-100 $\mathrm{mm} \mathrm{day}^{-1}$ ) and highintensity (above $100 \mathrm{~mm} \mathrm{day}^{-1}$ ) rainfall among all the regions. Another interesting feature is that the probability of extreme rainfall above $100 \mathrm{~mm}$ day $^{-1}$ is very less for all the countries, but the number of rainy days with rainfall intensity above $100 \mathrm{~mm} \mathrm{day}^{-1}$ is more over Sri Lanka, Bangladesh, Myanmar and Thailand than over India, Nepal and Bhutan.

\section{Summary and conclusions}

In this paper, the RegCM4 model has been simulated over the BIMSTEC region to evaluate the model performance in simulating some of the salient features of mean temperature, monsoon mean circulation and rainfall variability during the summer monsoon season. Considering the fact that climate change is recognised as the greatest long-term threat to the BIMSTEC region, we have examined the model simulation for the present climatology of the region to test the suitability of the model for the future climate change projections. The model performances are tested against the observation by keeping the hypothesis that if the model represents the present climate reasonably well, then it will also create confidence in the future climate change projections. The results show that the spatial distribution of the presentday temperature simulated by RegCM4 under the Grell scheme is not consistent with the observed dataset as simulation temperature results show a cold bias of $2-6^{\circ} \mathrm{C}$ in land regions of most of the BIMSTEC region. Further, the RegCM4 performance is quite reasonable while assessing seasonal rainfall with CRU (over land) and GPCP (both over land and ocean) observed data sets for the few regions of BIMSTEC. It is seen that the model generated spatial rainfall distributions match reasonably well with the observation for countries like India, Myanmar and Thailand. However, the model underestimates the rainfall over Bhutan, Nepal and Bangladesh and overestimates it over Sri Lanka. A common feature related to PDF distribution of daily rainfall for some of the homogeneous regions in the study area shows that the lower the rainfall intensity $\left(0-10 \mathrm{~mm}\right.$ day $\left.^{-1}\right)$, the more frequently it occurs as the frequency reaches near $90 \%$, and conversely, the higher the rainfall intensity, the less frequently it occurs (frequency reduces to 0.001). It is also found that the model has a poor skill in simulating the monthly scale seasonal rainfall variability over a few of the homogeneous regions of BIMSTEC. Furthermore, the model realistically captures the general structure of the lower level $(850 \mathrm{hPa})$ tropospheric monsoon circulations. Nepal and Bhutan have more biases in wind compared to the rest of the regions. Again, the model produces a slightly weaker cross equatorial flow and Somali jet (easterly bias) and stronger wind over the north Arabian Sea (westerly bias). Overall, the model is able to capture the strength and the direction of the lower tropospheric westerlies.

In general, the overall performance of the model while simulating monsoon temperature, rainfall and circulations is satisfactory only for a few BIMSTEC countries, specifically, over the Indian regions. In this aspect, our results are consistent with the results from a few previous studies over India, which show that the Grell scheme performed better than the other schemes in simulating both the temperature and rainfall (Dash et al. 2006; Sinha et al. 2013; Nayak et al. 2017; Maity et al. 2017). Further work is being planned to undertake climate simulations by downscaling through GCM 
outputs by RegCM4 with different combinations of convective and land surface schemes over the BIMSTEC countries in more detail.

\section{Acknowledgements}

The authors are thankful to the International Centre for Theoretical Physics (ICTP) for making available the RegCM4 model with LBC data for the simulations used in this study. They would like to take this opportunity to acknowledge the Head, NCMRWF for the vision and foresight which inspired them to initiate the climate change research in the BIMSTEC centre for weather and climate. They would also like to acknowledge the DST Centre of Excellence in Climate Modeling for the support to carry out the manuscript revision work.

\section{References}

Alam M and Tshering D 2004 Adverse impacts of climate change on development of Bhutan: Integrating adaptation into policies and activities; Working Paper No. 2, CLACC, Bhutan, 42p.

Ali A 1999 Climate change impacts and adaptation assessment in Bangladesh; Clim. Res. 12 109-116.

Anubhav C and Domri A P 2017 Assessment of CORDEXSouth Asia experiments for monsoonal precipitation over Himalayan region for future climate; Clim. Dyn., https:// doi.org/10.1007/s00382-017-3789-4.

Bal P K, Ramachandran A, Geetha R, Bhaskaran B, Thirumurugan P, Indumathi J N and Jayanthi N 2015 Climate change projections for Tamil Nadu, India: Deriving highresolution climate data by a downscaling approach using PRECIS; Theor. Appl. Climatol. 123(3-4) 523-535.

Bal P K, Ramachandran A, Palanivelu K, Thirumurugan P, Geetha R and Bhaskaran B 2016 Climate change projections over India by a downscaling approach using PRECIS; Asia-Pac. J. Atmos. Sci. 52(4) 353-369.

Bhaskaran B, Ramachandran A, Jones R and MoufoumaOkia W 2012 Regional climate model applications on sub-regional scales over the Indian monsoon region: The role of domain size on downscaling uncertainty; J. Geophys. Res. 117 D10113, https://doi.org/10.1029/ 2012JD017956.

BIMSTEC Report 2014 Ministry of External Affairs; https://www.mea.gov.in/Portal/ForeignRelation/BIMST EC_Brief_February_2014.pdf.

Burt T P and Weerasinghe K D N 2014 Rainfall distributions in Sri Lanka in time and space: An analysis based on daily rainfall data; Climate 2 242-263, https://doi.org/ $10.3390 /$ cli2040242.

Climate Profile for India 2010 Met Monograph No. Environment Meteorology-01/2010; http://www.imd.gov.in/doc/ climate_profile.pdf.
Dash S K, Shekhar M S and Singh G P 2006 Simulation of Indian summer monsoon circulation and rainfall using RegCM3; Theor. Appl. Climatol. 86 161-172, https://doi. org/10.1007/s00704-006-0204-1.

Gadgil S, Vinayachandran P N, Francis P A and Gadgil S 2004 Extremes of the Indian summer monsoon rainfall, ENSO and equatorial Indian Ocean oscillation; Geophys. Res. Lett. 31 L12213.

Giorgi F, Marinucci M R and Bates G T 1993 Development of a second generation regional climate model (RegCM2). part I: Boundary-layer and radiative transfer processes; Mon. Weather Rev. 121 2794-2813.

Government of Nepal 2015 Study of climate and climatic variation over Nepal; Nepal Hydrological and Meteorological Research Centre and Consultancy Pvt.

Grell G 1993 Prognostic evaluation of assumptions used by cumulus parameterizations; Mon. Weather Rev. 121764 787.

Grell G A, Dudhia J and Stauffer D 1994 A description of the fifth-generation Penn-State $=$ NCAR mesoscale model; NCAR Technical Report Note TN-398, National Center for Atmospheric Research, Boulder, Colorado, USA.

Halder S, Dirmeyer P A and Saha S K 2015 Sensitivity of the mean and variability of Indian summer monsoon to land surface schemes in RegCM4: Understanding coupled land-atmosphere feedbacks; J. Geophys. Res. Atmos. 120 9437-9458, https://doi.org/10.1002/2015JD023101.

Iqbal W, Syed F S, Sajjad H, Nikulin G, Kjellstrom E and Hannachi A 2017 Mean climate and representation of jet streams in the CORDEX South Asia simulations by the regional climate model RCA4; Theor. Appl. Climatol. 129(1-2) 1-19, https://doi.org/10.1007/ s00704-016-1755-4.

Kimpei I, Manabu D, Yamanaka Y M and Bijaya K V 2007 Precipitation in Nepal between 1987 and 1996; Int. J. Climatol. 27 1753-1762.

Kripalani R H, Oh J H, Kulkarni A, Sabade S S and Chaudhari H S 2007 South Asian summer monsoon precipitation variability: Coupled climate model simulations and projections under IPCC AR4; Theor. Appl. Climatol. 90 133-159, https://doi.org/10.1007/s00704-006-0282-0.

Maity S, Satyanarayana A N V, Mandal M and Nayak S 2017 Performance evaluation of land surface models and cumulus convection schemes in the simulation of Indian summer monsoon using a regional climate model; Atmos. Res. 197 21-41.

Mizanur R M, Nazrul I M, Ahsan U A and Georgi F 2012 Rainfall and temperature scenarios for Bangladesh for the middle of 21st century using RegCM; J. Earth Syst. Sci. 121(2) 287-295.

MPO 1991 National Water Management Plan: Phase II, Final Report, Master Planning Organization (MPO), Ministry of Irrigation, Water Development and Flood Control, Government of the People's Republic of Bangladesh, Dhaka.

Mukhopadhyay P, Taraphdar S, Goswami B N and Krishna Kumar K 2010 Indian summer monsoon precipitation climatology in a high resolution regional climate model: Impact of convective parameterization on systematic biases; Wea. Forecast. 25 369-387, https://doi.org/10. 1175/2009WAF2222320.1. 
Nayak S, Mandal M and Maity S 2017 Customization of regional climate model (RegCM4) over Indian region; Theor. Appl. Climatol. 127 153, https://doi.org/10.1007/ s00704-015-1630-8.

Pant G B and Rupa Kumar K 1997 Climates of South Asia; John Wiley \& Sons, Chichester, 320p, ISBN: 0-471-949485.

Partha Sarathi P, Ghosh S and Kumar P 2015 Possible future projection of Indian summer monsoon rainfall (ISMR) with the evaluation of model performance in coupled model inter-comparison project phase 5 (CMIP5); Global Planet. Change 129 92-106.

Parthasarathy B, Munot A A and Kothawale D R 1994 All India monthly and seasonal rainfall series: 1871-1993; Theor. Appl. Climatol. 49 217-224.

Pattnayak K C, Panda S K, Vaishali S and Dash S K 2017 Assessment of two versions of regional climate model in simulating the Indian summer monsoon over South Asia CORDEX domain; Clim. Dyn., https://doi.org/10.1007/ s00382-017-3792-9.

Roongroj C and Long S C 2007 Thailand daily rainfall and comparison with TRMM products; J. Hydrometeorol. 9, https://doi.org/10.1175/2007JHM876.1.

Rupa Kumar K and Ashrit R G 2001 Regional aspects of global climatic change simulation: Validation and assessment of climate response over Indian monsoon region to transient increase of greenhouse gases and sulphate aerosols; Mausam 52 229-244.

Sein Z M M, Ogwang B A, Ongoma V, Ogou F K and Batebana K 2015 Inter-annual variability of summer monsoon rainfall over Myanmar in relation to IOD and ENSO; J. Env. Agric. Sci. 4 28-36.

Shrestha B A, Wake P C, Mayewski A and Paul D J E 1999 Maximum temperature trends in the Himalaya and its vicinity: An analysis based on temperature records from Nepal for the period 1971-1994; J. Clim. 12 27752786 .

Sigdel M and Ikeda M 2012 Summer monsoon rainfall over Nepal related with large-scale atmospheric circulations; $J$. Earth Sci. Clim. Change 3 112, https://doi.org/10.4172/ 2157-7617.1000112.

Sinha P, Mohanty U C, Kar S C, Dash S K and Kumari S 2013 Sensitivity of the GCM driven summer monsoon simulations to cumulus parameterization schemes in nested RegCM3; Theor. Appl. Climatol. 112(1-2) 285306.

Sooraj K P, Pascal T and Prince X 2015 Sub-seasonal behaviour of Asian summer monsoon under a changing climate: Assessments using CMIP5 models; Clim. Dyn., https://doi.org/10.1007/s00382-015-2817-5. 